\title{
CONFLICT MANAGEMENT-RESOLUTION BASED ON TRUST?
}

\author{
Csilla Kohlhoffer-Mizser ${ }^{1, a, *}$ \\ ${ }^{1}$ Óbuda University Keleti Faculty of Business and Management, H-1084 Budapest, Tavaszmező street \\ 15-17, Hungary \\ amizser.csilla@kgk.uni-obuda.hu \\ "Corresponding author
}

Cite as: Kohlhoffer-Mizser, C. (2019). Conflict management-resolution based on trust? Ekonomickomanazerske spektrum, 13(1), 72-82.

Available at: dx.doi.org/10.26552/ems.2019.1.72-82

\begin{abstract}
There are several procedures worldwide persons can choose: the communication can be systematically facilitated with the aim of enabling the parties themselves to take responsibility for resolving their dispute. Alternative dispute resolution (out of court dispute resolution; extrajudicial dispute resolution) methods are to support natural persons and legal entities with several levels of conflict management. Reorganisation, resolution, restoration, evaluation, and transformation are present to give methods to the parties. Mediation is an opportunity in the subject of the alternative dispute resolution system, as one kind of procedures to solve a conflict. Mediation is based on the voluntary participation of the parties. Mediation is a procedure, in which an intermediary without adjudicatory powers -the mediatorsystematically facilitates communication between the parties with the aim of enabling the parties themselves to take responsibility for resolving their dispute. Persons sometimes decide very quickly, in the short term, sometimes the opposite: after months, after years, there is no decision made for several reasons. This study is focused on the actual status of the Hungarian society in connection with trials and conflict management. The paper aims to show the possible directions persons can decide in case of conflict. It is implicated to have progressive thinking about conflict resolution based on trust. It can be a change in societies to look at conflicts with another aspect. Persons can practice the "win-win situation" from the beginning of life; it can be implied in education. For future research, there is an aim to show every possible level where alternative dispute resolution is able to effect, practising nonviolent communication for the success of conflict management. Scholars and entrepreneurs can make use of this research to apply, use and train mediation tools when conflicts arise.
\end{abstract}

Keywords: conflict management, communication, decision, mediation, trust

JEL Classification: K00, K19, K36, K40, K42

\section{Introduction}

Various definitions of conflict are known worldwide and the definitions lived with historical changes, developed with people and with society. The conflict is a collision between the interests of natural or legal persons. Some of the conflicts are community conflicts, on the basis of common interest (state, local municipalities), some of the conflicts are based on individual interest, some conflict arises in the international level, between states, and we know, if states were in conflict in the history, there were often wars in connection with their conflicts. There are several examples in countries how to manage conflict and it is based on the historical- 
cultural development of each country. Through the interdependence of nations and cultures, disputes and dispute resolution processes need to account for much more than just the dispute itself. (Schuler, 2018) Research show paths of the negotiation space and negotiation strategies, agreements between nations, firms, and individuals facilitate trade and ensure smooth interaction. (Ott and Ghauri, 2018) Intercultural mediation is used when a conflict is determined or influenced by cultural differences and when its resolution takes these cultural differences into consideration, even if the cultural differences may not be the actual or original source of a dispute. (Schuler, 2018) Connecting that research is known to introduce that even agricultural income shocks drive the weather-crime relationship in developing countries. (Blakeslee and Fishmann, 2017) Social identity theory holds that an individual's self-concept is based not only on his or her personal identity but also on his or her group identity. (Reiche et al., 2015) International business scholars continue to struggle to theorize the relationship between country and cultural group boundaries. (Peterson et al., 2018) Asian example of research that conflict avoidance is common in East Asia and the Confucian notion of harmony is often invoked to explain this tendency. (Leung et al., 2002) There are several very important consequences of a person's, of a legal entity's or a society's behaviour in connection with decision making and solution finding in the case of emerged conflict. The important aspect of the financial background, of the question of how the choice of alternative dispute resolution influences the economy through the effects on economic life.

Successful modern societies are based on the willingness to cooperate, supported by GLOBE (www.globeproject.com) research with international comparisons. (Fürjes et al., 2010)

The aim of this paper is to introduce and stress, that every person, legal entity (state), the community has its own and special social-historical-financial development level. This paper wants to give an answer to the question if communication has an important role to reach a contract (one way of resolution) and if trust plays an important role in this procedure of communication (non-violent communication). Trust (Lazanyi, 2017), (McKnight, 1996), (Rousseau et al., 1998) can support conflict management and is able to give a snapshot of the general state of society and is capable of influencing person's (people, legal entities, communities, states) compliance with the law.

\section{Methodology}

The term „,conflict“ has no single clear meaning. Much of the confusion has been created by scholars in different disciplines who are interested in studying conflict. Reviews of the conflict literature show a conceptual sympathy for but a little consensual endorsement of any generally accepted definition of conflict. There is tremendous variance in conflict definitions that include a range of definitions for specific interests and a variety of general definitions that attempt to be all-inclusive. Conflict can be considered as a breakdown in the standard mechanisms of decision making so that an individual or group have difficulties in selecting an alternative. (Rahim, 2011)

While mediation is often thought of in the context of personal conflicts or family disputes, business owners realize that mediation services are available to resolve business-related disputes as well. Research emphasizes the importance of participation of organizations in participatory procedures, their involvement in development policy. (Kremer, 2004)

In the Hungarian legal regulation, there are several ways for persons how to resolve a conflict, how to resolve a dispute, how to continue with family members, neighbours, colleagues, business partners. Of course, courts fulfil the task to decide in the complaints of clients, to run the procedures of trials. 
Table 1 and Figure 1 displays what is the number of mediators and how many cases are there yearly to solve. From the year when the Act on Mediation has become in effect, from the year 2007, can we observe an increasing will of natural and legal persons to initiate mediation? The number of registered mediators at Ministry of Justice from 2010 to 2016 were the following:

Table 1: Registered mediators at Ministry of Justice Hungary 2010-2016

\begin{tabular}{cccccccc}
\hline & $\mathbf{2 0 1 0}$ & $\mathbf{2 0 1 1}$ & $\mathbf{2 0 1 2}$ & $\mathbf{2 0 1 3}$ & $\mathbf{2 0 1 4}$ & $\mathbf{2 0 1 5}$ & $\mathbf{2 0 1 6}$ \\
\hline $\begin{array}{c}\text { Registered } \\
\text { mediators } \\
\begin{array}{c}\text { at Ministry } \\
\text { of Justice }\end{array}\end{array}$ & 1272 & 1408 & 1578 & 1615 & 993 & 1041 & 1168 \\
\hline
\end{tabular}

Source: compilation by author according to Ministry of Justice, Hungary 2018

Figure 1: Registered mediators at Ministry of Justice Hungary 2010-2016

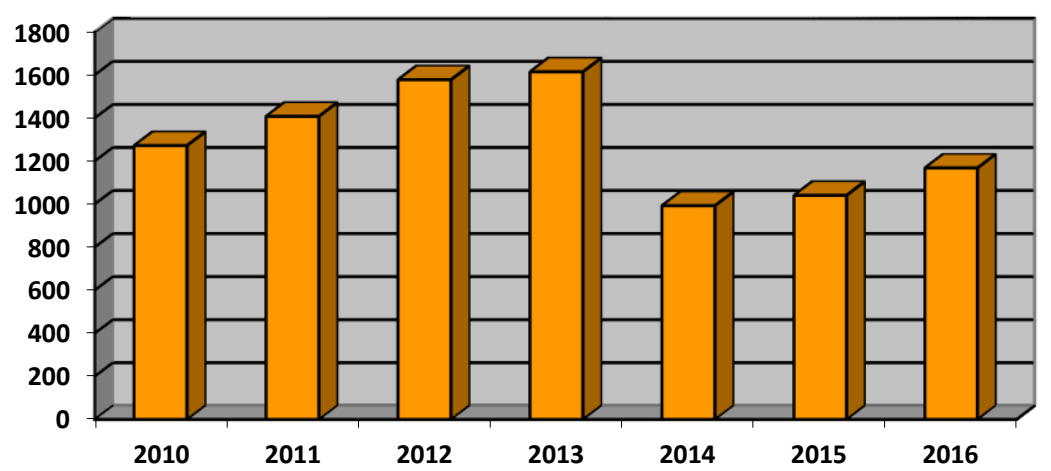

口registered mediators at

Ministry of Justice

Source: compilation by author according to Ministry of Justice, Hungary 2018

After three years of increasing in the number of registered mediators, a relapse can be observed in 2014, which has been followed by again with a slow increase in 2015 and 2016. The requirements of further training and continuative education of mediators included in the legal regulation may influence the issued registered mediators.

The numbers of incoming cases speak about confirmation in the statement according to the title 'It is bad to litigate' (Abraham and Eörsi, 2003). Perhaps people and decision makers change their minds and make the choice to choose alternative dispute resolution. Between 2010 and 2016, on the basis of data giving of registered mediators Table 2 and Figure 2 show the confirmation of mediated cases, separately the cases with a successful agreement at the end and separately the cases without a successful end.

Table 2: Incoming cases to registered mediators at Ministry of Justice Hungary 2010-2016

\begin{tabular}{cccccccc}
\hline & $\mathbf{2 0 1 0}$ & $\mathbf{2 0 1 1}$ & $\mathbf{2 0 1 2}$ & $\mathbf{2 0 1 3}$ & $\mathbf{2 0 1 4}$ & $\mathbf{2 0 1 5}$ & $\mathbf{2 0 1 6}$ \\
\hline successful & 216 & 708 & 370 & 589 & 851 & 864 & 983 \\
unsuccessful & 63 & 203 & 160 & 204 & 260 & 487 & 400 \\
\hline
\end{tabular}

Source: compilation by author according to Ministry of Justice, Hungary 2018 
Figure 2: Incoming cases to registered mediators at Ministry of Justice Hungary 2010-2016

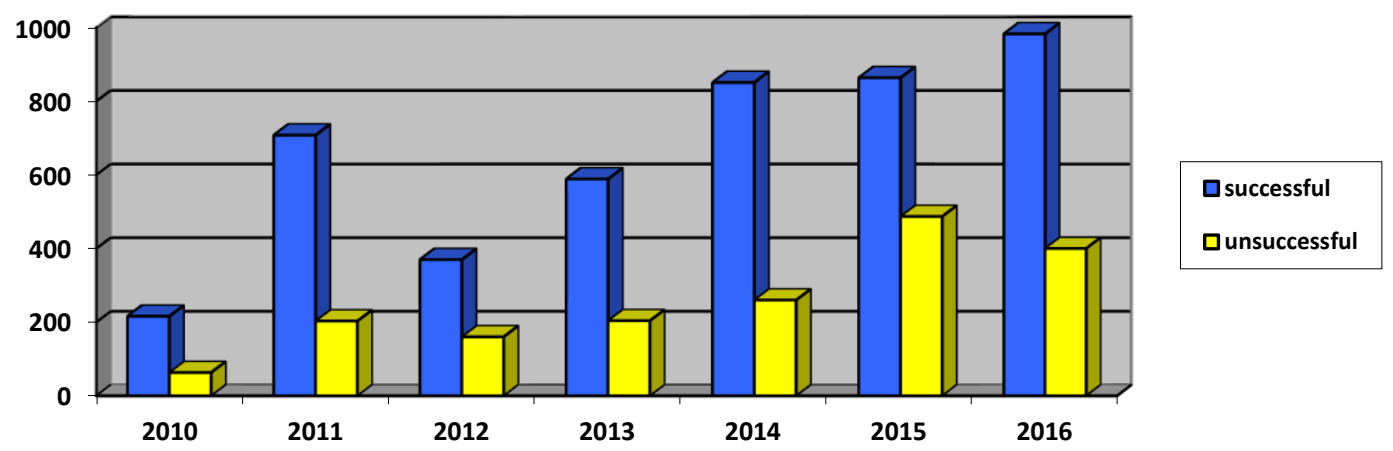

Source: compilation by author according to Ministry of Justice, Hungary 2018

\section{Results}

It is stated in Table 2/Figure 2, that from the year 2014 there is a stable increase in both successful and unsuccessful ended incoming cases. Starting from the figures in the table, it is expected that the number of people, firms or even communities that are choosing mediation will grow. Hopefully, this is despite the fact that Figure 3 shows the development of litigation cases in numbers, and these figures show almost stagnation, growth or only a minor decrease in litigation in all areas, except for one group of cases. This group is civil and business nonlitigious cases, which data for 2010 decreased by $39 \%$ compared to 2009 figures and then decreased by $83 \%$ from 2010 in 2011.

The development of civil lawsuits between 1990 and 2016 can be said that as a result of the fall in the number of non-litigious procedures, the burden of the courts has been reduced from the year 2010 as depicted in Figure 3. Based on data about the cases, trials at Hungarian courts provided by the Hungarian Central Statistical Office it is clear that, in 2010, the total number of cases, decreased by $24 \%$ from 2009 to 2010 . It is mostly affected by the legislative change that a major group of non-affiliated cases, payment orders are mostly made by notaries. 
Figure 3: Changing of cases, trials at Hungarian courts 1990-2016

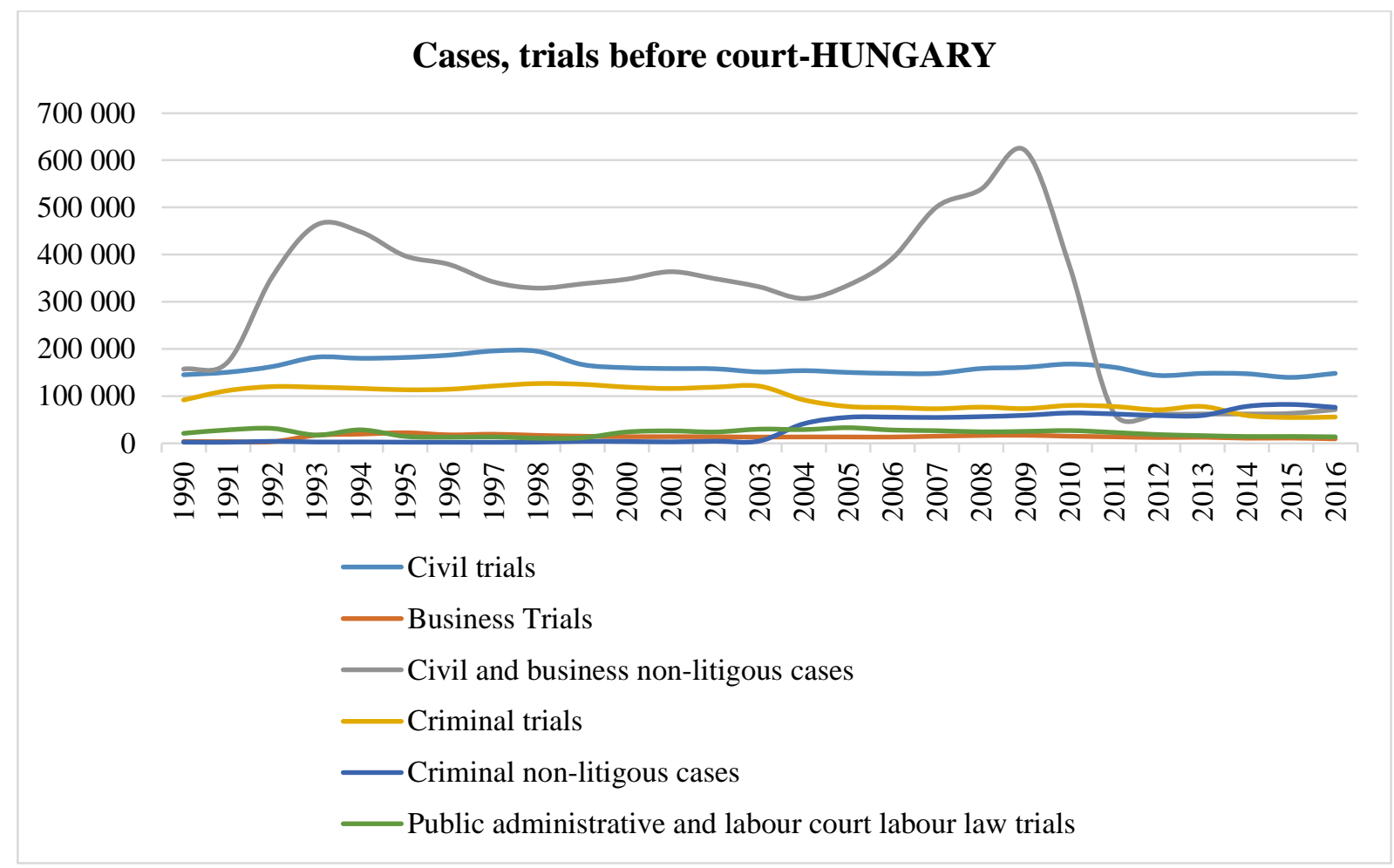

Source: compilation by author according to Hungarian Central Statistical Office Hungary, www.ksh.hu Decreasing number of civil and business non-litigious cases only, civil trials (1), criminal non-litigious cases (2), business trials (3), criminal trials (4), public administrative and labour law trials (5) Stagnate from (2)-(5).

\section{Discussion}

\subsection{Arbitration}

Our world has become more interconnected recently: we travel more, work or study abroad, family members live in different countries, we purchase goods online from all over the World. This new lifestyle requires that we use foreign financial services, or we use the products and services of our domestic financial service provider abroad when for example we make a payment, use ATMs, transfer money, purchase products and services. If things go well, it all seems perfect, however, when something goes wrong, and cross border financial disputes arise, we all want a quick, low cost, effective fix, not to mention we all want to do so in a language we are familiar with. If we face a domestic financial dispute - in which we have a complaint against a domestic financial service provider - we have a choice to turn to the alternative dispute resolution scheme that has jurisdiction to decide our case, as an example, if both parties to the dispute are residing in Hungary, this forum would be the Hungarian Financial Arbitration Board. (Cserepi, 2017) As a member of the FIN-Net international organisation, since 2013, the Board is also available for the management of cross-border consumer disputes; accordingly, it helps the respective consumers resolve their disputes with a financial service provider (bank, insurer, investment firm, etc.) operating in a different member state, relying on the alternative dispute resolution forum of the given country or, if this is not possible, find an alternative dispute resolution forum that is able to resolve the case through conciliation or mediation. These cases are the cross-border consumer disputes, the Hungarian rules of which are described in Articles 124-129 of Act CXXXIX of 2013. on the Hungarian National Bank. These rules are 
applicable when the respective consumer's home address or habitual residence is in Hungary and the registered office, business site or permanent establishment of the service provider is in a different state that is party to the Treaty on the European Economic Area; or the respective consumer's home address or habitual residence is in another EEA state, while the registered office of the organisation subject to oversight by the MNB is in Hungary.

The rules pertaining to the initiation and conducting of the proceedings in the case of crossborder financial consumer disputes are slightly different from the general rules. If the consumer has a home address or habitual residence in Hungary, while the financial service provider is an organisation with registered office in another EEA state, the extra condition for the initiation of the proceedings is the existence of a submission declaration of the service provider, which jointly represents the submission to the proceedings and the preliminary acceptance of the decision. However, in the absence of a submission declaration, the success of the resolution of the cross-border dispute is questionable; in such cases, the Board's function is limited to providing information and - if the petitioner so requests - forwarding the necessary materials. The Board has to inform the consumer about the alternative dispute resolution forum, participating in FIN-Net and residing in another EEA country, having power and competence in respect of the dispute, as well as on the special rules applicable to the procedure thereof, particularly on the need of preliminary consultation with the service provider and the deadlines prescribed for the initiation of the proceedings. If the consumer so requests, the consumer's petition, recorded on the standard form used in FIN-Net, must be sent to the FIN-Net member dispute resolution forum having power and competence in respect of the proceedings. Upon the existence of a submission declaration, the procedure is identical, with some exceptions, with the domestic procedure, the result of which - if the petition is substantiated - could be a settlement agreement, a binding resolution or, if the petition lacks grounding, the procedure is terminated. (Report on the activities of the Hungarian Financial Arbitration Board, 2017) Financial reconciliation is just one example of several alternative dispute resolution areas, the number of which has expanded over the past ten years.

\subsection{Trust-decision-connection}

The GLOBE survey -GLOBE Research Program- covers 62 countries (including Hungary, from European clusters to Eastern Europe with Albania, with Armenia, Greece, Kazakhstan, Poland, Russia and Slovenia), ranked Hungary 61st in the rankings, as last but one, examining the society's willingness to cooperate.

Eastern European cluster has a population of 232 million and a gross domestic product (GDP) of U.S. \$772 billion. The cluster's distinctive cultural practices are high power distance and high family and group collectivism. The region is facing significant challenges during its period of transition from communist philosophy to market-based economies. The participating managers value a much greater degree of the future and performance orientation but are strongly attached to their cultural heritage of deep family and group cohesion. They also highly value charismatic and team-oriented leadership. (Bakacsi et al., 2002)

On the basis of these facts, in the field of social cooperation, Hungarian is a self-interest driven, dissolving society that would surely be more successful if its members were to assume responsibility for the consequences of their acts. As responsibility and willingness to cooperate grow, and we learn to make as many common results as possible from a given situation, then wealth will grow healthily, emotionally and economically. The lack of cooperation will cause enormous damage to the economy, but it also has extraordinary potential for development, resulting in a change of social attitude, quantifiable economic results and savings. (Fürjes et al., 2010) Fortunately, since the above research, more than ten years have elapsed, and the 
development of mediation and financial reconciliation in this article has progressed along with the development of the entire alternative dispute resolution area, and the future is also determined by this trend.

The more we are connected technologically and economically, the more challenges we may face. Through the interdependence of nations and cultures, disputes and dispute resolution process need to account for much more than just the dispute itself. As we follow new social and political trends and developments, intercultural understanding is key to averting potential conflicts and promoting cross-border collaboration. Intercultural mediation is used when a conflict is determined or influenced by cultural differences and when its resolution takes these cultural differences into consideration, even if the cultural differences may not be the actual or original source of a dispute. (Schuler, 2018)

Apart from some of the highlighted Hungarian examples, they give an insight into where the alternative dispute resolution is today - alternative dispute resolution can be found in many places in the world. To strive for peaceful conflict management and peaceful resolution of disputes, today we call court mediation, mediation, conciliation, arbitration, litigation, and arbitration services as an alternative dispute resolution.

However, the field of business mediation cannot be clearly separated from other mediation types, business mediation often fuses with them, furthermore, research shows that mediation has to be viewed as complementary elements of an integrated system and that the key to successful dispute resolution in international business is a conscious and creative design of conflict management process. (Bühring-Uhle et al., 2006)

Mediation is a procedure, which may benefit the business. Parties, which worked out a consensus, are more willing to maintain further relations. Moreover, mutual trust is maintained. Research shows that trust is not only very important in business but it can play the most important role e.g. in the field of logistics when the question is about taking/providing services, however, price and flexibility do matter as well. (Bujdoso et al., 2009)

After mediation, trust may be even bigger than before the dispute as parties are more likely to perceive their business partners as reasonable and responsible people, with whom they can go through conflicts and resolve the problems in a proper manner, without court. (Zaleski, 2015)

Trust does not, of course, play a decisive role not only during the conflict management of legal entities but also in the conflict management of natural persons. Based on trust -this is the fundamental mediation process can work. Several studies work with buyer-seller conflict management, as Celuch et al. (2011) ascertain the aim to address how trust interacts with attributions to impact the effect of partner communication on conflict resolution perceptions in buyer-seller relationships.

Two conditions of trust are risk and independence. Three phases are building, stability and dissolution. (Rousseau et al., 1998) Trust can be conceptualized as an orientation toward society and toward others, that has social meaning beyond rational calculations. (Tyler, 1996)

Research examines environments in which agents are randomly matched to play a Prisoner's Dilemma, and each player observes a few of the partner's past actions against previous opponents. (Heller and Mohlin, 2017)

It is stated, the level of trust between the trustee and the truster (client) is defined by the sum of credibility, reliability and intimacy divided by the self-orientation. $\mathrm{T}=(\mathrm{C}+\mathrm{R}+\mathrm{I}) / \mathrm{S}$ Client can be a friend, family member, student, boss, direct report, or any other person you enter into a trust relationship with. (Greiner, 2013) Figure 4. gives a brief formula titled the trust equation based on the work of Maister et al. (2010). It records that trustworthiness is the summing up of credibility and reliability and intimacy divided by self-orientation. Research argues that social capital as proxied by trust increases aggregate productivity by affecting the organization of 
firms (Bloom et al., 2012) and that an institution-based view of international business strategy has emerged in emerging economies. (Peng et al., 2008)

Figure 4: The Trust Equation

\section{TRUST EQUATION}

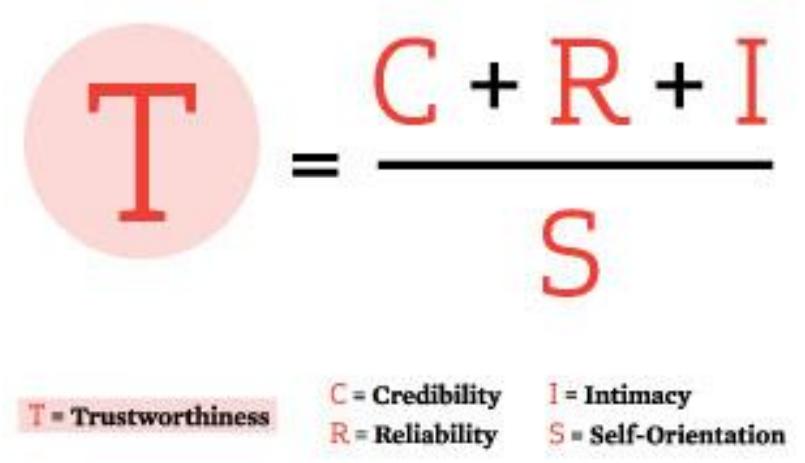

Source: compilation by author according to thegetralproject.com

Examining business conflict resolution, a proven relationship exists between leadership styles and conflict management styles among managers, while handling interpersonal conflict managers and subordinates. (Saeed et al., 2014) Karam et al. (2019) determined that leadership is one of the most studied phenomena in management. The research presents that identity, a person's sense of self, affects economic outcomes. (Akerlof and Kranton, 2000) Furthermore, unlocking the relationship between leadership and team performance and creativity communication and trust are keywords. Considerable theoretical and empirical work has identified a relationship between transformational leadership and team performance and creativity. (Boies et al., 2015)

Worldwide, NVC (nonviolent communication) now serves as a valuable resource for communities facing violent conflicts and severe ethnic, religious, or political tensions. (Rosenberg, 2015) The research deals with non-violence and pacifism in a row (Ramsbotham et al., 2011) and point out, that nonviolent communication facilitates the retrieval of the ethics of authenticity. (Nosek, 2012) Findings reveal that power distance between the meeting leader and attendees does relate positively to emotional labour, both surface and deep acting. (Erks et al., 2017)

It is important and relevant that the parties involved in the conflict can communicate with each other so that the existing conflict of interest is further aggravated by further diligence, lingering litigation, but, as far as possible, resolving the dispute and settling the dispute with an agreement. This requires cooperation between the parties.

What does make peace possible, what kind of resources are needed for peacebuilding? It is abundantly clear across our globe, both historically and at present, that the expenditures and resources consumed by a war far outpace those allocated for building peace. Without adequate resources, explicit preparation and commitment over time, peace will remain a distant ideal rather than a practical goal. The primary goal with regard to resources is to find ways to support, implement, and sustain the building of an infrastructure for peace over the long term. To achieve this goal, we need an expanded understanding of resources. The approach to the question of resources for peace under two broad headings: socioeconomic and sociocultural. The former suggests that resources do, indeed, involve a monetary aspect, but that equally critical is the 
sociological dimension in the disbursement of funds. The latter suggests that people and their various cultural traditions for building peace are also primary resources. (Lederach, 1997)

The perspectives of conflict resolution differ from the perspective of conflict transformation. One is not weaker or worse than the other, but the key issue, the focus, the aim, the progress, the time frame and the interpretation of the conflict is - as illustrated in Figure 5.

Figure 5: Conflict Transformation or Conflict Solution?

\begin{tabular}{|c|c|c|}
\hline & Perspective of conflict resolution & Perspective of conflict forming \\
\hline Key question & How can the dispute be closed? & $\begin{array}{l}\text { How can the destructive process be closed and } \\
\text { instead wanted to build on it? (examples: new level of } \\
\text { connection, restoration of original state) }\end{array}$ \\
\hline Focus & $\begin{array}{l}\text { CONTENT FOCUS. (What is the } \\
\text { essence of the dispute, what is it about, what } \\
\text { are the participants in the conflict trying to } \\
\text { solve?) }\end{array}$ & $\begin{array}{l}\text { CONNECTION FOCUS. (what was the } \\
\text { relationship between the parties involved in the } \\
\text { conflict, what would they like to see as a relationship } \\
\text { in the future?) }\end{array}$ \\
\hline Aim & $\begin{array}{l}\text { Finding a solution and finding a solution } \\
\text { to the crisis-causing problem. }\end{array}$ & $\begin{array}{l}\text { Initiating a constructive change that includes but } \\
\text { is not limited to solving the immediate problem. }\end{array}$ \\
\hline Progress & $\begin{array}{l}\text { It is based on a direct relationship where } \\
\text { fractures have appeared. }\end{array}$ & $\begin{array}{l}\text { The problem that has arisen is considered as an } \\
\text { opportunity to intervene in the system of } \\
\text { relationships. }\end{array}$ \\
\hline Time frame & Short term problem-solving. & $\begin{array}{l}\text { From medium to long-term problem solving, } \\
\text { deliberately responding to the crisis and not led by the } \\
\text { crisis. }\end{array}$ \\
\hline $\begin{array}{l}\text { Interpretation of } \\
\text { the conflict }\end{array}$ & $\begin{array}{l}\text { It interprets the need to reverse the } \\
\text { conflict dynamics. }\end{array}$ & It interprets the conflict as a dynamic link system. \\
\hline
\end{tabular}

Source: compilation by author according to editing by the author based on Pallai (2012): Procedures for Participation in Settlement and Settlement of Municipal and Community Disputes - Proposal for a Consistent Terminology. Magyar Közigazgatás 2.1. Március p.86

\section{Conclusion}

Conflict management is a creative activity that can be used to develop profitable professional levels in society for individuals, businesses and focus on the dynamism and balance of conflict and harmony. Conflict management is one of the ways of achieving peace. Peace is nothing more than a change in the form of conflict or in the antagonists or in the objects of the conflict, or finally in the chances of selection. (Coser, 1998) According to the social meaning of conflict and peace (Lederach,1995) persons, organizations, working places, families, neighbours, states, consumers in different cultures can bring themselves to a position to doable to make their own decisions. The socio-moral climate is positively related to innovation. The positive relation between the socio-moral climate and innovation was mediated stepwise through debate and decision comprehensiveness. (Seyr and Vollmer, 2014)

This paper aims to be forward-looking in the sense that it emphasizes the importance of trust as a basis for conflict, its management, connectivity and peaceful settlement, as well as all connections. In trust-based relationships liability has a significant role, to be liable for our decisions we may recognized as a profit in society, and look at alternative dispute resolution approach as a progress, society is going to focus on in the way that this process can bring for the individual as well as for the community the greatest benefit.

Funding: This research received no external funding

Author Contributions: The author confirms being the sole contributor of this work and approved it for publication. 
Conflict of Interest Statement: The author declares that the research was conducted in the absence of any commercial or financial relationships that could be construed as a potential conflict of interest.

\section{References}

Abraham, Z. \& Eörsi, M. (2003). Pereskedni rossz-Mediáció: A szelíd konfliktuskezelés (It Is Bad to Litigate Mediation, the gentle conflict management). Budapest, Minerva.

Akerlof, G. \& Kranton R. E. (2000). Economics and identity. The Quarterly Journal of Economics, 115(3), 715753.

Bakacsi, Gy., Takacs, S., Karacsonyi, A. \& Imrek, V. (2002). Eastern European cluster: Tradition and transition. Journal of World Business, 37(1), 69-80.

Boies, K., Fiset J. \& Gill, J. (2015). Communication and trust are key: Unlocking the relationship between leadership and team performance and creativity. The Leadership Quarterly, 26, 1080-1094.

Bujdoso, L., Hartvanyi, T. \& Nagy V. (2009). Critical decision making issues for logistic services from users' perspective in Hungary. Proceedings of the MEB 2009 - 7th International Conference on Management, Enterprise and Benchmarking.

Bühring-Uhle, C. Kirchhoff, L. \& Scherer, G. (2006). Arbitration and mediation in international business. Kluwer Law International.

Blakeslee, D. S. \& Fishmann, R. (2017). Weather shocks, agriculture, and crime evidence from India. Journal of Human Resources, 53(3), 750-782.

Bloom, N., Sadun, R. \& Reenen, J. (2012). The organization of firms across countries. The Quarterly Journal of Economics, 127(4), 1663-1705.

Cases, trials at Hungarian courts 2004-2016, Central office of statistics Hungary. Available at: www.ksh.hu.

Celuch, K., Bantham H. J. \& Kasouf, J. C. (2011). The role of trust in buyer-seller conflict management. Journal of Business Research, 64, 1082-1088.

Coser, L. A. (1998). The functions of social conflict. The International Library of Sociology.

Cserepi, J. (2017). FIN NET and INFO Network: International networks of alternative dispute resolution schemes and entities. AKV Európai Szemle.

Erks, R., Nyquist, E., Allen, J. \& Rogelberg, S. (2017). Regulating emotions in response to power distance in meetings. Journal of Management Development, 36(10), 1247-1259.

Fürjes, B., Kremer, A. \& Somodi, E. (2010). A mediáció és a birósági eljárások kapcsolata Magyarországon. 2009/2010. évi kísérleti bírósági mediációs program kiértékelése. Budapest Available at: http://www.mediacio.hu/files/tanulmany_mediacios_programrol.pdf

Greiner, R. (2013). The trust equation. Available at: http://robertgreiner.com/2013/04/the-trust-equation.

Heller, Y. \& Mohlin, E. (2017). Observations on cooperation. The Review of Economic Studies, 85(4), $2253-2282$.

Karam, E. P., Hu, J., Davison, R. B., Juravich, M., Nahrgang J. D., Humphrey, S. E. \& DeRue, S. D. (2019). Illuminating the 'Face' of justice: A meta-analytic examination of leadership and organizational justice. Journal of Management Studies, 56(1), 134-171.

Kremer, A. (2004) Social impact assessment and social participation. The region-regional development, policy, administration and e-government. transition, competitiveness and economic growth. Akadémiai Kiadó.

Lazanyi, K. (2017). Innovation - the role of trust. Serbian Journal of Management, 12(2), 317-331.

Lederach, J. P. (1995). Proposing for peace across cultures. Syracuse University Press.

Lederach, J. P. (1997). Sustainable reconciliation in divided societies. Washington DC, USIP.

Leung, K., Koch, P. T. \& Lu, L. (2002). A dualistic model of harmony and its implications for conflict management. Asia Pacific Journal of Management, 19, 201-220.

Maister, D. H., Green, C. H. \& Galford, R. M. (2010). The trusted advisor. The Free Press, New York.

McKnight, D. H. \& Chervany, N. L. (1996). The meanings of trust. Citesser.

Ministry of Justice, Hungary data giving (2018).

Nosek, M. (2012). Nonviolent communication: A dialogical retrieval of the ethic of authenticity. SAGE, London.

Ott, U. F. \& Ghauri, P. N. (2018). Brexit negotiations: From negotiation space to agreement zones. Journal of International Business Studies, 50(1), 137-149.

Pallai, K. (2012). Részvételi eljárások települési és Közösségi viták és konfliktusok kezelésére-Javaslat egy konzisztens terminológiára. Magyar Közigazgatás 2.1. Március, 86.

Peng, M. W., Wang, D. Y. L. \& Jiang, Y. (2008). An institution-based view of international business strategy: a focus on emerging economies. Journal of International Business Studies, 39(5), 920-936. 
Peterson, M. F., Søndergaard, M. \& Kara, A. (2018). Traversing cultural boundaries in IB: The complex relationships between explicit country and implicit cultural group boundaries at multiple levels. Journal of International Business Studies, 49(8), 1081-1099.

Rahim, A. M. (2011). Managing conflict in organizations. Tylor \& Francis, New York.

Ramsbotham, O., Miall, H. \& Woodhouse, T. (2011). Contemporary conflict resolution. Polity Press.

Reiche, S. B., Harzing, A-W. \& Pudelko, M. (2015). Why and how does shared language affect subsidiary knowledge inflows? A social identity perspective. Journal of International Business Studies, 46, 528-551.

Report on the activities of the Hungarian arbitration board, Budapest, 2017 . Available at: http://www.mnb.hu/letoltes/pbt-2017-hun-0301-2.pdf.

Rosenberg, M. B. (2015). Nonviolent communication: A language of life. 3rdEdition, Puddle Dancer Press, CA.

Rousseau, D. M., Sitkin, B. S., Burt, R. S. \& Camerer, C. (1998). Not so different after all: A cross-discipline view of trust. Academy of Management Review, 393-404.

Saeed, T., Almas, S., Anis-ul-Haq, M. \& Niazi, G. (2014). Leadership styles: Relationship with conflict management styles. International Journal of Conflict Management, 25(3), 214-225.

Seyr, S. \& Vollmer, A. (2014). Socio-moral climate, debate, and decision comprehensiveness interplay for team innovation. International Journal of Conflict Management, 25(2), 105-123.

Schuler, S. (2018). Mediation in intercultural conflicts: How far can mediation help? CEDR Article. Available at: https://www.cedr.com/articles/?item=Mediation-in-Intercultural-Conflicts-How-far-can-mediation-help.

Tyler, T. R. \& Kramer, R. M. (1996). Trust in organizations: Frontiers of theory and research. SAGE.

Zaleski, M. (2015). Why mediation? EMNI European Mediation Network Initiative Available at: www.europeanmediation.eu/whymediation.html.

www.globeproject.com. 